\title{
The Controversy that Isn't: The Debate over Daniel J. Goldhagen's Hitler's Willing Executioners in Comparative Perspective
}

\author{
Gavriel D. Rosenfeld \\ grosenfeld@fairfield.edu
}

Follow this and additional works at: https://digitalcommons.fairfield.edu/history-facultypubs Copyright 1999 Cambridge University Press.

\section{Peer Reviewed}

\section{Repository Citation}

Rosenfeld, Gavriel D., "The Controversy that Isn't: The Debate over Daniel J. Goldhagen's Hitler's Willing Executioners in Comparative Perspective" (1999). History Faculty Publications. 57.

https://digitalcommons.fairfield.edu/history-facultypubs/57

\section{Published Citation}

Rosenfeld, G. (1999) "The Controversy that Isn't: The Debate over Daniel J. Goldhagen's Hitler's Willing Executioners in Comparative Perspective," Contemporary European History, Volume 8, Nr. 2, 1999, pp. 249-273.

This item has been accepted for inclusion in DigitalCommons@Fairfield by an authorized administrator of DigitalCommons@Fairfield. It is brought to you by DigitalCommons@Fairfield with permission from the rightsholder(s) and is protected by copyright and/or related rights. You are free to use this item in any way that is permitted by the copyright and related rights legislation that applies to your use. For other uses, you need to obtain permission from the rights-holder(s) directly, unless additional rights are indicated by a Creative Commons license in the record and/or on the work itself. For more information, please contact digitalcommons@fairfield.edu. 


\title{
The Controversy That Isn't: The
}

\section{Debate over Daniel J. Goldhagen's}

\section{Hitler's Willing Executioners in}

\section{Comparative Perspective}

\author{
GAVRIEL D. ROSENFELD
}

Karl Marx's celebrated observation that 'all the events . . . of great importance in world history occur . . . twice ... [The] first time as tragedy, the second as farce' may seem out of place in a discussion of the Holocaust. However, this very dictum appears to be confirmed by the recent controversy over Daniel J. Goldhagen's Hitler's Willing Executioners. Since its publication in the United States in late March, and in Germany in early August, I996, Goldhagen's book has been the subject of immense media attention. Not only has it been reviewed by numerous scholars and journalists in a wide array of publications, it has also been discussed in front of mass audiences on television, debated in public symposia, and fought over in cyberspace. Most of the critical attention given to Hitler's Willing Executioners has focused understandably upon its explanation of the Holocaust as a product of the uniquely rabid anti-Semitism of 'ordinary Germans'. The reasons why the book has caused such an international furor, however, have been given far less attention. There was, to be sure, much initial speculation about the likelihood of the book sparking a substantial scholarly controversy. Some observers in Germany even predicted the outbreak of a new 'historians' debate'. ${ }^{1}$ Such predictions, though, have proved to be largely inaccurate. Although Goldhagen's book has been subjected to many vehement attacks, it has prompted little substantive debate to speak of. Debate, after all, requires two sides. In the case of Hitler's Willing Executioners, however, the match-up has been absurdly imbalanced. Apart from some early support in popular reviews in the United States and more recent expressions of sympathy from the general public in Germany, Goldhagen has for the most part stood alone against his critics. Indeed, the near-unanimity of scholarly criticism directed at Hitler's Willing Executioners has been acknowledged even by Goldhagen himself, who has responded by expressing indignation that all of his critics have so profoundly misread his book. The wide span separating the two 'sides' of the Goldhagen controversy raises doubts

1 This position was represented most actively by Die Zeit, which first provided a forum for many historians to engage Goldhagen. See 'Hitlers willige Mordgesellen', Die Zeit, I2 Apr. I996, I. See also Jost Nolte, 'Sisyphos ist Deutscher', Die Welt, г6 Apr. 1996. 
about its very character as a debate. There is much, in fact, about the furor surrounding Hitler's Willing Executioners that has a palpably artificial feel about it. Indeed, in comparison with previous controversies over the Third Reich and the Holocaust, it is not an exaggeration to say that the Goldhagen controversy exhibits farcical traits.

One question among many that deserves to be raised is whether the controversy surrounding Hitler's Willing Executioners has erupted for reasons larger than the book itself. Generally speaking, truly substantive historiographical debates are either sparked by pathbreaking works of scholarship or by broader political disputes. Recent controversies over the dropping of the atomic bomb over Hiroshima, the origins and course of the French Revolution, and the early history of the state of Israel are several examples. ${ }^{2}$ Goldhagen's book, in contrast, fails to measure up on both of these counts. The consensus of the scholarly community is that, despite its claims to have radically reconceptualized Holocaust scholarship, Hitler's Willing Executioners represents, at best, only a fairly modest scholarly advance. The possibility that his book's critical reception reflects larger political trends - for example, as some German critics initially speculated, the surfacing of latent political concerns among Americans about German reunification - likewise seems doubtful. The hype surrounding Hitler's Willing Executioners thus seems out of proportion to its actual scholarly value. It seems from closely examining the debate as it has progressed so far that the Goldhagen affair represents a case of induced controversy, of controversy for its own sake.

This appears to be particularly true when one contrasts the furor sparked by Hitler's Willing Executioners with previous historiographical controversies involving the recent German past. Since the book's appearance, various critics have attempted to identify precedents for the Goldhagen controversy. Some have compared the impact of Hitler's Willing Executioners with that caused by Fritz Fischer's controversial study of the outbreak of the First World War, Griff nach der Weltmacht - a book which, when published in 196I, launched a prolonged debate among West German historians about Germany's responsibility for the First World War and subsequently gave rise to a more introspective, self-critical trend in West German historical scholarship of the Third Reich. ${ }^{3}$ The impact of Goldhagen's book has also been compared with that of Hannah Arendt's Eichmann in Jerusalem, an accusatory work which, in addition to introducing the concept of the 'banality of evil', caused a stir among historians in the United States and Israel with its claims about the 'complicity' of the Jews in their own murders. ${ }^{4}$ More frequently, Hitler's Willing Executioners has been seen as capable of provoking a conflict similar to the Historikerstreit, or 'Historians' Debate', of the mid-I980s about the uniqueness of the

2 See Michael Hogan (ed.), Hiroshima in History and Memory (New York: Cambridge University Press, 1995), Steven Laurence Kaplan, Farewell Revolution: The Historians' Freud, France, 1789/1989 (Ithaca, New York: Cornell University Press, I995), and the recent special issue of History and Memory, entitled 'Israeli Historiography Revisited', Spring/Summer 1995.

3 Volker Ullrich, 'Vertraute Töne', Die Zeit, I4 Jun. I996, 45.

4 Berel Lang, 'The Blame Game', Moment, August, I996, 84-5. 
Holocaust. ${ }^{5}$ These comparisons, while intriguing, are unsatisfying in various ways, however. One important reason, after all, for the controversy surrounding Hitler's Willing Executioners (at least in the Federal Republic, where a knee-jerk defensiveness was the early response) is Goldhagen's 'outsider' status as an American (and, to boot, a Jewish) scholar writing on the most sensitive topic of recent German history. In contrast, the Fischer controversy and the Historians' Debate were largely internal German affairs, while the Arendt book stirred emotions most forcefully within Jewish cricles. A more instructive comparison, and in many ways the most obvious precedent to the Goldhagen controversy, was the furor caused by a work of another American: William L. Shirer's The Rise and Fall of the Third Reich in 1960-62. Comparing the debates sparked by Shirer's and Goldhagen's books reveals many instructive parallels about the differences in scholarly and public perceptions of the Third Reich. At the same time, however, such a comparison - between the first postwar study of the Nazi era to spark international controversy and the most recent book to do so - reveals the insubstantial dimensions of the debate surrounding the latter.

In the vast historiography on the Nazi period, The Rise and Fall of the Third Reich occupies a unique place. ${ }^{6}$ As the first comprehensive postwar study of Hitler's rise to power and of the subsequent Nazi dictatorship, it ranks as the best-selling work ever written on the subject. The commercial success of The Rise and Fall of the Third Reich was immediate; when published in 1960, the massive book - nearly 1,250 pages in length - was a runaway best-seller in the United States, selling over I million copies in the first year alone. This success, moreover, has continued up to the present day. In the thirty-five years since its appearance, it has sold many millions of copies, a fact that has given it the reputation of being the best-selling work of history of all time. The Rise and Fall of the Third Reich, moreover, was as controversial as it was commercially successful. While it garnered great critical acclaim in the United States, the book was bitterly attacked by critics in West Germany, who uniformly condemned it as a mean-spirited, anti-German polemic that distorted German history and threatened to damage German-American relations. The numerous attacks levelled against the book by German critics, however, did not prevent the German version of the book, Aufstieg und Fall des Dritten Reiches, from being on the bestseller list for six months after its initial publication in autumn 1961. There, too, the controversy and commercial success of the book were mutually sustaining. Over the span of two years, I960-62, Shirer's book sparked the most extended public debate about the German past since the end of the Second World War.

What was it about The Rise and Fall of the Third Reich that caused such sharply differing reactions in the United States and West Germany? To begin with, Shirer's

5 Volker Ullrich, 'Hitlers willige Mordgesellen', Die Zeit, I2 Apr. I996, I; see also Nomi Morris, 'Owning up to Evil', Maclean's, 3 Jun. I996, 59.

6 For a full discussion of The Rise and Fall of the Third Reich and its impact in the early I96os, see Gavriel D. Rosenfeld, 'The Reception of William L. Shirer's The Rise and Fall of the Third Reich in the United States and West Germany, I960-62', Journal of Contemporary History, I (1994), 95-I29. 
basic explanation of the roots of the Third Reich was controversial from a historiographical standpoint. From the outset of his book, Shirer made abundantly clear his belief that 'Nazism and the Third Reich ... were but a logical continuation of German history'. Rooted in longstanding traditions of militarism and authoritarianism, supported by a submissive and obedient German population, the Third Reich, he argued, was the logical capstone of a tradition of national deviance. This was, to be sure, hardly a novel argument. Indeed, it marked a reversion to the notorious 'Luther to Hitler' view of German history, an overdrawn, deterministic perspective that was commonly espoused during the I930s and I940sprecisely the period in which Shirer acquired his first-hand understanding of the Nazi state as a journalist based in Berlin. By I960, however, this explanatory schema for the Third Reich was increasingly rejected, although not altogether abandoned, by historians and political scientists. At this point in time, Cold War tensions had created an intellectual climate receptive to the theoretical paradigm of totalitarianism - the belief that the Nazi and Soviet dictatorships were fundamentally similar and historically rooted in wider European social, economic, and political trends. The extent to which these two competing historiographical explanations of the Nazi state were accepted in the United States and West Germany during the early i96os was one important factor in determining the contrasting reactions to The Rise and Fall of the Third Reich. ${ }^{7}$

In the United States, the reaction to The Rise and Fall of the Third Reich was on the whole positive and, at times, effusive. Among Shirer's journalistic colleagues, the book received widespread acclaim, being hailed by John Gunther, for instance, as 'one of the most spectacular stories ever told' and by Orville Prescott as 'one of the most important works of history of our time'. Historians, too, such as Hugh R. Trevor-Roper, Geoffrey Barraclough and Gordon Craig, described the book as 'masterly' and 'monumental' and supported its emphasis on the Third Reich's German roots. Such praise, moreover, was neither shallow nor fleeting. Indeed, the broad-based respect for The Rise and Fall of the Third Reich was clearly demonstrated in early I96I, when it was awarded the prestigious National Book Award. To be sure, the praise directed towards the book was not unanimous. Many scholars disputed both its claims of originality and its thesis that the origins of Nazism lay primarily in the particular features of German history. Speaking for many, one of Shirer's most vociferous critics, the German historian Klaus Epstein, emphatically dismissed what he called the journalist's 'rewarming of the wartime tale that German history is a one-way road leading from Luther to Hitler' and asserted that this thesis reflected not only Shirer's inability 'to . . . adequately comprehend the nature of a modern totalitarian state' but his 'systematic prejudice when dealing with Germany's cultural heritage'. Such objections were typical of much of the scholarly reaction to The Rise and Fall of the Third Reich. Given the fact that Shirer was a journalist and an outsider to academia, the negative reaction to his work was not surprising. For the 
most part, however, scholarly criticisms of Shirer's book were not heard in the deafening roar of critical acclaim bestowed upon it. $^{8}$

In West Germany, however, negative criticism was the standard response to The Rise and Fall of the Third Reich. In numerous reviews of the book in the press, German critics uniformly attacked The Rise and Fall of the Third Reich on a variety of counts. Both journalists and historians claimed that Shirer's view of German history was hopelessly flawed, describing it as 'simplistic', reminiscent of 'the clichés employed by Allied propaganda in the First and Second World Wars', and barely of 'elementary school sophistication'. Asserting that his work was 'based on the state of knowledge [of the Nazi period] of 1950', German reviewers attacked Shirer for having ignored the theoretical model of totalitarianism which then held sway in the Federal Republic as the dominant explanatory model for the Third Reich. As Martin Broszat and others noted, 'a history of National Socialism that is worthy of the name . . . cannot . . . be written by someone who completely passes over the core of the problem - totalitarianism in its specifically National Socialist form'. Beyond calling into question Shirer's scholarly credentials, moreover, German reviewers levelled ad hominem attacks against him, calling him a German-hater who viewed the Germans as a 'dangerous race' and approached his subject with the 'soul . . . of a Nuremberg prosecutor'. Shirer, in short, was seen as handicapped by longstanding prejudices against Germans, which prevented him from accepting recent scholarship that exonerated the nation from exclusive responsibility for the Nazi disaster. And yet, the controversy was not merely a matter of competing historiographical models. ${ }^{9}$

The vehemence of the German reaction to the The Rise and Fall of the Third Reich points to a second and equally significant reason for the furor it evoked: Cold War politics. As critical reviewers in the United States and the Federal Republic forcefully argued, Shirer's resurrection of the memory of Nazism - and, more importantly, its specifically German roots - threatened to undermine GermanAmerican relations at a particularly sensitive point in the Cold War conflict. During the period I958-6I, a unique constellation of events made it appear as if public concern about Germany's Nazi past might threaten the stability of the Western alliance. The infamous wave of swastika daubings on synagogues in Germany at the end of 1959 and the beginning of 1960 , the simultaneous disclosure of the presence of ex-Nazis in the Bonn government, and, most dramatically, the capture and subsequent trial of Adolf Eichmann in May 1960, placed Nazism once again at the centre of worldwide media attention. At the same time, the West's weak response to the Berlin crisis of 1958 and its total acquiescence in the erection of the Berlin wall in I96I led many Germans to fear a link between the new unflattering light on their Nazi past and weakening American support for the Federal Republic. ${ }^{10}$

According to many observers in Germany, The Rise and Fall of the Third Reich was

$8 \quad$ Ibid., pp. Iо5-8.

Ibid., pp. I $14-17$.

10 Ibid., pp. $\mathrm{IO}_{3}-4$. 
a 'dangerous book' that contributed directly to this worrisome political situation. In fact, Shirer did raise implicit questions about the Federal Republic's postwar trustworthiness in his study, noting that the nation's 'spiritual break with the West ... has not been healed to this day' and insisting that it was 'too early to speak . . . with any certainty' about the destruction of its militaristic and authoritarian traditions. In West Germany, many critics worried about what effect the book's commercial success in the United States portended for American views of their nation. While some saw The Rise and Fall of the Third Reich as responsible for 'producing the scepticism that has recently arisen in America with regard to the Germans', others argued, more shrilly, that the book had 'fanned the flames of a new wave of anti-German sentiment'. For such critical observers, the belief that Shirer's work was influencing the views of hundreds of thousands of American readers was extremely worrisome. Such concerns reached as high up as Federal Chancellor Konrad Adenauer, who attacked Shirer as a 'German-hater' and argued that his book was 'extremely harmful to German-American relations'. As part of a larger effort at public relations damage-control, the Bonn government took the unusual step in late I96I of compiling a twenty-four page pamphlet of negative reviews of the book and distributing it to numerous American newspaper editors and book reviewers. Still, some German reviewers conceded that the damage had already been done. Although it had been widely hoped that Americans had forgotten about the Federal Republic's Nazi past over the course of the two nations' postwar anti-communist alliance, the book's success made clear, as one observer in the Frankfurter Allgemeine Zeitung pointed out, that 'a good many people, even in allied states, have not forgotten'. ${ }^{11}$

What was the ultimate significance of the international furor surrounding The Rise and Fall of the Third Reich? In terms of scholarship on the Nazi period, the book had little immediate impact. Most German historians in the early I960s were not prepared, in the first place, to heed Shirer's implicit call to redirect their focus away from the concept of totalitarianism and towards the deeper German roots of Nazism. Any debate that might have ensued between Shirer and his German critics was forestalled, moreover, when he cancelled his planned tour of the country after being informed that he would probably face numerous lawsuits once he entered German territory. ${ }^{12}$ And yet, even though the direct scholarly impact of Shirer's book was minimal, it was instrumental in reviving popular attention towards a period of history that had been gradually marginalised in memory. Since the late I940s and throughout the decade of the I950s, the concerns of most Americans and Germans understandably had been dominated less by Nazis than by communists. The publication of Shirer's book, aided by renewed international attention towards Germany's Nazi past and geopolitical present, however, altered this state of affairs for good. Indeed, in West Germany, the growing recognition of the widespread

11 Ibid., pp. 102-3, I18-20.

12 William L. Shirer, Twentieth Century Journey: A Native's Return, 1945-1988 (New York: Simon and Schuster, 1990), 440. Manuscripts Department, Lilly Library, Indiana University/Epstein mss (MDLLIU/Em), letter from William Shirer to Fritz Epstein, 2I Sep. I96I. 
interest in the Third Reich together with the increasing frustration that - as the Süddeutsche Zeitung noted - 'we allow the great subject of our history . . . to be taken away from us by foreigners', gradually prompted German historians to take a new, self-critical look at their own history. As the historiographical turn of the I96os would reveal (beginning with the vigorous German debate over Fritz Fischer's book, Griff nach der Weltmacht, in 1964, and followed by the study of the German Sonderweg), a new generation of German historians increasingly began to identify distinct lines of continuity between the Third Reich and previous eras of the German past. That historians increasingly began to approach Shirer's own position (albeit in a far more sophisticated and nuanced manner) attests to his indirect role in promoting the long German struggle to 'come to terms' with the Nazi past (known in German as Vergangenheitsbewältigung). Although Shirer as an outsider was unable to topple the reigning views of German history, the impact of his book rendered them vulnerable and ultimately led them to be challenged by the Germans themselves.

Shirer's contribution to this process of confronting the past, however, has generally been ignored. He himself remained a tragic figure of sorts. Frustrated by the lack of respect granted him in Germany, he did not return to the country until I985, at which point the controversy over US President Ronald Reagan's visit to the Bitburg military cemetery left him newly pessimistic about the future. Only gradually did German historians come to recognise the value of Shirer's work and understand the reasons for the widespread resistance to The Rise and Fall of the Third Reich within their country in the early I960s. ${ }^{13}$ Today, however, his reputation has been belatedly restored. When he died in late I992, Shirer was remembered by one of the leading German historians of the Nazi period, Hans Mommsen, as a 'brilliant observer of German affairs'. ${ }^{14}$ In this sense, his view of German history can be seen as having been somewhat ahead of its time.

Whether or not the same can be said about Daniel J. Goldhagen's book can be answered, in part, by comparing the debate sparked by Hitler's Willing Executioners to that caused by Shirer's The Rise and Fall of the Third Reich. Numerous similarities can be noted between the two books. Both were highly provocative, offering similar theses that diverged from the scholarly consensus of the times. In the same way, for example, that Shirer aimed to redirect attention towards the German roots of (and the German people's support for) National Socialism and the Third Reich, Goldhagen stressed the German dimensions of the Holocaust. Both books, indeed, advocated differing versions of the 'Luther to Hitler' view of German history, seeking the causes of the Nazi disaster in a specifically deviant German national context rather than in factors typical of broader European or modern developments. As is by now well known, Goldhagen adamantly rejected explaining the Holocaust according to any theories that possess universalistic implications, be they coercion, obedience, peer pressure, bureaucratic indifference, or the fragmented nature of

13 Volker Ullrich, 'Die schreckliche Wildnis Deutschland', Die Zeit, I8 Mar. 1994, I7-I8.

14 Hans Mommsen, 'Schlüssel zur Gewaltherrschaft', Die Süddeutsche Zeitung (SZ), 30 Dec. I993, IO. 
decision-making. ${ }^{15}$ Instead, he focuses insistently upon the role of a deep-rooted German tradition of anti-Semitism. 'The conclusion of this book', Goldhagen states, 'is that anti-Semitism moved ... ordinary Germans ... to slaughter Jews'; 'Germans' anti-Semitic beliefs . . . were the central causal agent of the Holocaust.' ${ }^{16}$ In the same way that Shirer abandoned complicated, ideal-typical theoretical constructs such as totalitarianism to explain the genesis and functioning of the Nazi state in favour of an argument of national particularity, Goldhagen rejects more theoretical explanations in favour of a view that centred on an onerous 'eliminationist' anti-Semitism present in Germany since the early nineteenth century. Needless to say, such a view, emphasising continuity rather than rupture, teleology rather than contingency, is highly controversial, yet understandably popular in its simplicity and surface logic.

Indeed, Goldhagen's simple explanation for the Holocaust in Hitler's Willing Executioners no doubt contributed substantially to the book's swift attainment of bestseller status. In the United States, it was first on the bestseller list of Publisher's Weekly in April and remained near the bottom of the top fifteen hardback nonfiction sellers nationwide for almost three months until June, after which time it dropped off the list altogether. ${ }^{17}$ Compared to Shirer's impressive year-and-a-half run on the American bestseller list in I960-6I, this showing was quite modest. Yet, in Germany, the sales of Goldhagen's book were more noteworthy. The book sold out its first printing of 40,000 in a week, a number that doubled within the subsequent three weeks. ${ }^{18}$ Over two years since its appearance in Germany, the book has sold well over I00,000 copies and has been a constant presence on Der Spiegel's bestseller list. The commercial success of Hitler's Willing Executioners in Germany thus substantially surpassed that of The Rise and Fall of the Third Reich in I96I-62.

Far more notable than the sales of Goldhagen's book, of course, was the media frenzy surrounding it. Although quickly subjected to withering criticism, Hitler's Willing Executioners was initially greeted with considerable media attention and acclaim in the United States. Some portion of this phenomenon was the result of relentless promotion. In contrast to Shirer, who was rather modest about the virtues of his book, Goldhagen emphatically asserted the originality, innovativeness, and importance of his study. ${ }^{19}$ Marketing hype also contributed to the early success of

15 These general theories have been advanced by Christopher Browning in his study, Ordinary Men (New York; Harperperennial, I992), a book which Goldhagen uses as a foil for his own work. Much of Goldhagen's critique of Browning takes place in the footnotes of Hitler's Willing Executioners.

16 Daniel J. Goldhagen, Hitler's Willing Executioners: Ordinary Germans and the Holocaust (New York: Alfred A. Knopf, I996), 9.

17 By way of comparison, Goldhagen's book was on the New York Times Book Review's bestseller list for a total of eleven weeks in 1996, from April to the end of June.

18 'Goldhagen Sells Out in Germany', Forward, 23 Aug. 1996; since early September 1996, the book has stood as high as number two on Der Spiegel's bestseller list.

19 Shirer, for example, noted in the foreword to his book that 'I found it extremely difficult and not always possible to learn the exact truth about Hitler's Germany'. William L. Shirer, The Rise and Fall of the Third Reich (New York: Simon and Schuster, I960), xi. He also modestly conceded that his 'interpretations ... . will be disputed by many' (p. xii). 
Hitler's Willing Executioners. The book's publisher Alfred A. Knopf organised a shrewd and predictably glitzy campaign on behalf of the book, touting it as 'an explosive historical work of the utmost originality and importance that will radically transform our understanding of the Holocaust and of Nazi Germany'. Such hyperbolic praise, to be sure, also surrounded The Rise and Fall of the Third Reich, whose publisher, Simon and Schuster, heralded it in 1960 as 'one of the most important stories ever told' and possibly 'the definitive history of one of the greatest and most frightening chapters in the history of mankind'. Puffs of this kind are understandable from publishing firms whose primary business is to sell books. Yet, as frequently happens in the world of publishing, the line between hype and critical praise seems to have been blurred in the case of Hitler's Willing Executioners. The glowing mini-reviews written by Stanley Hoffman and Simon Schama and distributed by Knopf in its advance publicity for the book may be of doubtful validity, given that neither scholar (though well-respected in his respective field) is an acknowledged expert in the area of Holocaust studies. ${ }^{20}$ Other positive reviews of the book also must be evaluated in light of their authors' lack of scholarly expertise in the field. The grandiose claims of journalists, for example, that Hitler's Willing Executioners was 'the most important book ever published about the Holocaust', that it would 'revolutionise Holocaust studies', that it was 'historic' and 'masterly', seem to be driven more by the dynamics of our present-day, blurbocratic mass media than by any careful consideration of the book's merits and flaws. ${ }^{21}$

The praise for Hitler's Willing Executioners, indeed, has thus far been significantly outweighed by the avalanche of criticism that has been directed towards it. Unlike The Rise and Fall of the Third Reich, over which American and German reviewers divided sharply, the negative response to Goldhagen's study among American and German reviewers, journalists as well as historians, has been remarkably consistent. ${ }^{22}$ Much of the criticism has been harsh. In countless review articles and, more recently, entire books, American critics have dismissed Hitler's Willing Executioners as 'unoriginal', 'simplistic', 'reductionistic' and 'mechanistic', and have accused Gold-

20 Hoffmann gave the book a positive review, calling it 'overwhelming and devastating', in Foreign Affairs, May/June I996, I44. Fritz Stern and Raul Hilberg cite the importance of promotional hype for the book's success. See Fritz Stern, 'The Goldhagen Controversy', Foreign Affairs, November/December 1996, I 38; and Raul Hilberg, 'The Goldhagen Phenomenon', Critical Inquiry, Summer I997, 72 I-8.

21 See New York Times advertisement for the book, 4 April I996, B5. A. M. Rosenthal praised the book in his brief essay, 'Some Ordinary Germans', The New York Times, 2 Apr. 1996. Robert Andersen calls the book 'brilliant' in 'Extraordinary Evil: New Look at the Holocaust Finds the Answer to "Why?" Buried Deep in a Nation's Soul', Chicago Tribune, 2 I April I996. See also Jack Schwartz's positive review in Newsday, 24 Mar. I996. The positive review by Elie Wiesel, one of the most recognisable public figure associated with the Holocaust, represents an exception to the trend of ebullient reviews by non-experts. Wiesel, however, stops short of crediting Goldhagen with explaining the Holocaust, an event which for him remains 'unexplainable'. Wiesel's review can be found in Julius H. Schoeps (ed.), Ein Volk von Mördern? Die Dokumentation zur Goldhagen-Kontroverse um die Rolle der Deutschen im Holocaust (Hamburg: Hoffman und Campe, I996), 44-7.

22 A collection of reviews, entitled Ein Volk von Mördern? Die Dokumentation zur GoldhagenKontroverse um die Rolle der Deutschen im Holocaust and edited by Julius H. Schoeps (Hamburg: Hoffman \& Campe, 1996), contains many of the important German reviews but is more sparse in its selection of American reviews. 
hagen of selectively using archival sources in a 'biased' manner, of 'hyping the Holocaust', and (least plausibly) of being an 'holocaust ideologue' who has depicted the Holocaust through an 'ultra-Zionist lens' in order to promote the political agenda of the 'Holocaust Studies Industry'. ${ }^{23}$ Like their American colleagues, most German critics, especially early on, were extremely severe in their treatment of Goldhagen's study, attacking it as 'an awful book' of 'minimal value' that 'proves nothing'. ${ }^{24}$ More charitable reviewers in both countries, while recognising that Hitler's Willing Executioners is, in fact, a serious study of some of the perpetrators of the Holocaust, have cast doubt upon its hubristic claim to have overturned reigning conceptions of the Holocaust with a radically original thesis. ${ }^{25}$ To a certain extent, the sharply negative tone of the American reviews of Hitler's Willing Executioners can be attributed to the fact that Goldhagen has gained considerable commercial success as a disciplinary outsider; like Shirer, who achieved great success as a journalist, Goldhagen is a political scientist who has entered a field largely populated by historians (whom he has understandably angered by challenging their work). Unlike

23 Criticisms of the book's claim to originality can be found in the following reviews: Berel Lang, 'The Blame Game', Moment, August 1996, 86; Robert Wistrich, 'Helping Hitler', Commentary, July I996, 30; Omer Bartov, 'Ordinary Monsters', The New Republic, 29 Apr. I996, 34; Gordon A. Craig, 'How Hell Worked', The New York Review of Books, I8 Apr. I996, 4, 7; David Schoenbaum, 'Ordinary People?' National Review, I Jul. I996, 55; Yehuda Bauer, 'Why the Germans?', Humanistic Judaism, Summer 1996, 36-9; Henry Friedlander, 'Daniel Jonah Goldhagen, Hitler's Willing Executioners', German Studies Review, 3, October 1996, 578; and Stern, 'The Goldhagen Controversy', I29. The book has been deemed 'simplistic' by Nomi Morris, 'Owning up to evil', MacLean's, 3 Jun. I996, 59, 'reductionist' by Jeremy D. Noakes, 'No ordinary People', Times Literary Supplement, 7 Jun. I996, IO, and 'mechanistic' by Stephen Aschheim in 'Reconceiving the Holocaust?' Tikkun, II, 4 (I996), 64. Ruth Bettina Birn was among the most direct in criticising Goldhagen for allowing his thesis to dictate the presentation of his evidence, Ruth Bettina Birn, 'Revising the Holocaust', The Historical Journal, I (1997), I95-215. For more on the theme of hype, see Franklin H. Littell (ed.), Hyping the Holocaust: Scholars Answer Goldhagen (East Rockaway, N.Y.: Cummings and Hathaway, 1997). The accusation that Goldhagen was a Zionist ideologue surfaced in two extremely critical essays by Norman Finkelstein which, while offering substantive criticisms of Goldhagen's work, concluded with wildly polemical and unfair speculations Goldhagen's putative role as the chief representative of the (allegedly) politically driven and scholarly worthless field of 'Holocaust studies'. Revealingly, Finkelstein declined to identify any representatives of this scholarly field, leaving one little choice but to regard it as a straw man argument, perfectly suited for him to topple as a means of promoting his own political agenda: Norman Finkelstein, 'Daniel Jonah Goldhagen's "Crazy" Thesis: A Critique of Hitler's Willing Executioners', New Left Review, July/August 1997, 39-87. Norman Finkelstein and Ruth Bettina Birn, A Nation on Trial: The Goldhagen Thesis and Historical Truth (New York: Henry Holt, I998).

24 Eberhard Jäckel, 'Einfach ein schlechtes Buch', Die Zeit, 17 May 1996, Is; Norbert Frei, 'Ein Volk von Endlösern?' SZ, I3/I4 Apr. 1996, I3; Frank Schirrmacher, 'Hitlers Code', FAZ, I5 Apr. 1996, 31. For another scathing review see Rudolf Augstein, 'Der Soziologe als Scharfrichter', Der Spiegel, I6 (1996), 29-30.

25 More moderately critical reviews include John Elson, 'What Did They Know?', Time, I Apr. 1996; Volker Berghahn, 'The Road to Extermination', The New York Times Book Review, I 4 Apr. I996, 6-7; and Dietrich Orlow, 'The Roots of Nazism', The Boston Globe, 24 Mar. 1996, B36. In a similar vein, Josef Joffe has written several ambiguous reviews of the book, calling it 'a brilliant contribution', on the one hand, yet asserting that Goldhagen's basic premise 'crumbles' in the light of countervailing evidence. See Josef Joffe, 'Goldhagen in Germany', The New York Review of Books, 28 Nov. I996 as well as 'Hitlers willfährige Henker', Die Süddeutsche Zeitung, I3/14 Apr. 1996, I3. One of the more wellbalanced and thorough German reviews of the book is Dieter Pohl's 'Die Holocaust-Forschung und Goldhagen's Thesen', Vierteljahrshefte für Zeitgeschichte, I (January I997), I-49. 
The Rise and Fall of the Third Reich, however, which is regarded as a relatively solid (if now largely outdated) work, the critics of Hitler's Willing Executioners have shown it to be marred by a litany of serious analytical and methodological shortcomings. As such, it fails to realise its stated ambition to be 'a radical revision of what has until now been written'. ${ }^{26}$ Goldhagen's explanation of the Holocaust is, in fact, not new; where it is new, moreover, it does not fully explain the Holocaust. In surveying the critical reaction to the book in the United States and Germany, therefore, one inevitably is forced to raise questions about the qualitative nature of the Goldhagen 'controversy' itself.

Nearly all reviewers have pointed out the shortcomings of Goldhagen's discussion of German anti-Semitism. Eager to demonstrate the existence of a nearly universal anti-Semitism among the German people, Goldhagen downplayed evidence to the contrary, identifying seamless continuities in place of a highly differentiated historical reality. His view of the pervasiveness of a uniquely pernicious 'eliminationist' antiSemitism cannot account, first of all, for the fact that, as a result of the (admittedly slow) process of emancipation and assimilation, Jews not only rose to positions of preeminence in German cultural, intellectual and political life throughout the nineteenth and twentieth centuries but frequently intermarried with Christians or were accepted as converts to Christianity. ${ }^{27}$ Goldhagen has also been criticised for exaggerating the extent and severity of anti-Semitism in nineteenth- and early twentieth-century Germany. His erroneous claim that antisemitic political parties enjoyed a majority in the Reichstag and his dilution of the political power of the Social Democrats (SPD, whose leader, August Bebel, had famously decried antiSemitism as the 'socialism of fools') have been pointed out, as has his conflation of racial anti-Semitism (which enjoyed more of a fringe status) and the more common non-racial forms of anti-Semitism. ${ }^{28}$ Despite his elaborate theoretical arguments to the contrary, Goldhagen's view of anti-Semitism seems to be largely ahistorical; he devoted little attention, for example, to the radicalising impact that the loss of the First World War and the Bolshevik Revolution had on the qualitative nature and

26 Goldhagen, Hitler's Willing Executioners, 9.

27 See Clive James, 'Blaming the Germans', The New Yorker, 22 Apr. 1996, 49; 'If all were guilty, none were', Economist, 27 Apr. 1996, 91; Wistrich, 'Helping Hitler', 30. Steven Aschheim points out that intermarriage rates were above IO-I $3 \%$ before I9I4 and double that in Weimar. Aschheim, 'Reconceiving the Holocaust?', 63. Such facts do not accord well, to say the least, with Goldhagen's assertion that 'the vast majority of Germans had little or no contact with Jews'. Goldhagen, Hitler's Willing Executioners, 78. For if this many Germans and Jews were intermarrying, many more were clearly acquainted. German critics likewise stressed the integration of Jews in pre-Nazi Germany. 'Ein Volk von Dämonen?' Der Spiegel, 2I (1996), 60-4, Heinrich Jaenecke, 'Die Deutschen: ein Volk von Antisemiten?' Stern, 30 (1996), I30. See also letter to the editor by Marion Gräfin Dönhoff, The New York Review of Books, 23 May 1996, 52.

28 On the composition of the Reichstag and the strength of the SPD see Wistrich, 'Helping Hitler', 29; Noakes, 'No ordinary People', 9; Aschheim, 'Reconceiving the Holocaust?', 63, Ulrich Herbert, 'Aus der Mitte der Gesellschaft,' Die Zeit, I4 Jun. I996, 5; Gordon Craig, letter to the editor, The New York Review of Books, 23 May 1996, 52. Goldhagen's undifferentiated use of anti-Semitism is discussed by Christopher Browning, 'Daniel Goldhagen's Willing Executioners', History and Memory, 97-8; Robert Leicht, 'Warum der Streit um die Studie sich lohnt', Die Zeit, 6 Sep. 1996. For a general critique see Hans Mommsen, 'Die dünne Patina der Zivilisation', Die Zeit, 30 Aug. I996, I4-I 5. 
quantitative spread of anti-Semitism in Weimar Germany, seeing such developments as a mere adjustment of a long extant eliminationist model. ${ }^{29}$

Beyond the realm of German history itself, Goldhagen's view of anti-Semitism has been censured for a lack of comparative perspective. This is a crucial omission, given Goldhagen's emphasis on the uniqueness of German anti-Semitism - a quality that can only be demonstrated through an approach that is comparative in nature. So singular does Goldhagen view the pervasiveness and perniciousness of eliminationist anti-Semitism in nineteenth- and twentieth-century Germany to be that he claims that the nation had 'a radically different culture', was not 'normal', and should not be seen as 'more or less like us'; rather, German culture must be viewed in the same way that 'an anthropologist, disembarking on unknown shores', would examine an exotic, foreign people. ${ }^{30}$ As many reviewers have pointed out, however, France during the Dreyfus Affair, Russia under the tsars, and Austria in the era of Lueger and Schönerer experienced far more antisemitic violence than Wilhelmine Germany ever did. ${ }^{31}$ To this list should be added the quantum leap in antisemitic violence during and after the First World War, in which an estimated 250,000 Jews (identified frequently as traitorous Bolsheviks) were massacred in bloody pogroms and mass executions by Ukranians, Russians and Poles. In short, although Goldhagen identified a qualitatively more severe brand of anti-Semitism in Germany, his view is contradicted by the sorry evidence supplied by Germany's neighbours.

In addition to attacking Goldhagen's view of German anti-Semitism, his numerous critics have questioned his analysis of its specific role in motivating the German perpetrators of the Holocaust. Various reviewers have questioned Goldhagen's seeming diminution of the role played by the dictatorial Nazi system itself - in particular, his failure to address the role of the state propaganda apparatus in sanctioning and encouraging latent hatreds, his underestimation of the effectiveness of the police state in silencing critics of antisemitic actions, and, above all, his blurring of the substantial difference in antisemitic attitudes held by the fanatical Nazi leadership on the one hand and the broader German citizenry on the other. ${ }^{32}$

29 Wistrich, 'Helping Hitler', 29; Stern, 'The Goldhagen Controversy', I31. Other examples of Goldhagen's ahistorical, undifferentiated exaggerations include his claims that 'conservatives and Volkisch nationalists ... formed the vast majority of the population' (when? and what of the working class?), that 'the ubiquitous anti-Semitism that existed in 1800 and in 1850 [eras, by the way, before the term was even coined] became . . . more intense and . . . deadly as the century was drawing to a close' (a claim refuted by the decline in political anti-Semitism at this time), and that 'racial anti-Semitism was the salient form of anti-Semitism in Germany' (when, he does not specify). Goldhagen, Hitler's Willing Executioners, 56, 74 .

30 Goldhagen, Hitler's Willing Executioners, is, 27. Goldhagen concludes: 'German anti-Semitism was sui generis'. Goldhagen, Hitler's Willing Executioners, 4I9.

31 Schoenbaum, 'Ordinary People?', 55; Wistrich, 'Helping Hitler', 29; Noakes, 'No Ordinary People', 9; Stern, 'The Goldhagen Controversy', I29; Hans-Ulrich Wehler, 'Wie ein Stachel im Fleisch', Die Zeit, 24 May 1996, 40.

32 On the differences between the anti-Semitism of the Nazi leadership and the masses see Wistrich, 'Helping Hitler', 30, Noakes, 'No Ordinary People', 9. A particular glaring example is his (unprovable) claim that 'a near universal acceptance of the central aspects of the Nazi image of Jews characterised the German people'. Goldhagen, Hitler's Willing Executioners, 442. On the role of incessant 
Moreover, some have criticised Goldhagen's failure to contextualise the Holocaust within the Nazis' overall plan for a racial utopia, from which Slavs, Gypsies, and the handicapped - in addition to Jews - were to be violently excluded. ${ }^{33}$ Still others have refuted Goldhagen's assertions of the broad-based approval of the Holocaust among the German population by stressing the regime's desire to maintain a veil of secrecy around its worst crimes, citing, in particular, Heinrich Himmler's notorious speech to the SS in Posen on 4 October 1943 in which he referred to the Holocaust as 'the most glorious page in our history . . . which shall never be written'. ${ }^{34}$

Beyond objections to Goldhagen's reading of the history of Nazi Germany, many have cited the absence of a comparative framework for analysing the specific role of anti-Semitism in the crimes of the Holocaust. Some, for example, have shown that hatred was not a necessary criterion for mass killings; Christopher Browning, for example, argued that the participation of thirteen members of Police Battalion IOI from Luxemburg in the killing of Jews could not have been the result of a German brand of anti-Semitism. ${ }^{35}$ Other massacres during the Second World War reveal the relative insignificance of hatred as a primary motive for murder: the cold-blooded execution of over 2 I,000 Polish officers by Soviet troops (who were presumably not consumed by hatred, yet nevertheless proceeded to kill their defenceless prisoners) in the Katyn forest and at other sites in 1940, as well as the notorious massacres committed against non-Jews by German army and SS units at Oradour (French), Malmédy (Americans), Lidice (Czechs), and the Ardeatine caves (Italians). Other critics have argued that hatred was not solely a German affair, pointing to other Europeans who were just as antisemitic as Germans and were able to kill Jews en masse and in cold blood. Significant numbers of Lithuanians, Latvians, Ukrainians, and Romanians distinguished themselves during the Second World War for their participation in bloody massacres of Jews. ${ }^{36}$ If, as Goldhagen insists, the Germans were not 'normal' because of their anti-Semitism, then neither were these other peoples - a fact which ultimately invalidates any assertion of German uniqueness. Indeed, in sharing such company with other nations' willing executioners, the Germans must be seen either as not so unlike everyone else or as part of a larger collective of 'uniquely' abnormal peoples - an oxymoronical concept that calls into

antisemitic propaganda under the Nazis see Bartov, 'Ordinary Monsters', 35; Jaenecke, 'Die Deutschen', I3 I; on Nazi repression of dissident opinion, see James, 'Blaming the Germans', 47-8 and 'Ein Volk von Dämonen?' 77.

33 James, 'Blaming the Germans', 50; Wehler, 'Wie en Stachel', 40; Aschheim, 'Reconceiving the Holocaust?' 64-5; In his article 'Hitler's Willing Executioners: Privileging Jewish Lives, Privileging Antisemitism', Jonathan Petrie reminds readers that the Nazis killed millions of Polish civilians and Russian POWs. In The Genocide Forum, June I996, 2-3.

34 Noakes, 'No Ordinary People', Io; 'Ein Volk von Dämonen?' 52, 76-7; Aschheim, 'Reconceiving the Holocaust?' 63; James, 'Blaming the Germans', 47; Himmler's words are cited in Saul Friedlander, Memory, History, and the Extermination of the Jews (Bloomington, Indiana: Indiana University Press, 1993), I05.

35 Browning, 'Goldhagen's Willing Executioners', 94-6.

36 Wehler, 'Wie ein Stachel', 40; Jäckel, 'Einfach ein schlechtes Buch', I5; Joffe, 'Hitlers willfährige Henker', David Cesarani, 'Hitler's Willing Executioners', New Statesman and Society, I5 Apr. I996; 'If all were guilty, none were', Economist, 91. 
question the very idea of normalcy. Finally, the occurrence of so many other episodes of mass murder in the twentieth century - the Armenians massacred by the Turks, the victims of the Stalinist purges, of Maoist revolutionary violence, of Pol Pot and the Khmer Rouge, of mutual Hutu and Tutsi antagonisms, and of the Yugoslav civil war - also suggests that other factors, rooted in the nebulous concept of modernity, must be at work besides simple hatred which, after all, has regrettably been in existence for many centuries prior to this one. ${ }^{37}$

Yet, even apart from the trenchant critiques of Goldhagen's analysis of antiSemitism and its contribution to mass murder, his book falls short of its claim to have revised fundamentally our understanding of the Holocaust by neglecting its unique feature: the gas chambers. ${ }^{38}$ Having noted at the outset of Hitler's Willing Executioners that the surfeit of scholarly analysis on the gas chambers justifies omitting them from his analysis, Goldhagen marginalises their importance throughout the book, calling them 'epiphenomenal' and 'not an essential development' in the overall German plan of killing Jews, which would have continued even without their invention. ${ }^{39}$ This counterfactual hypothesis is, of course, invalidated by the historical record. The Germans did invent the gas chambers and for a reason: to make their genocidal campaign both more efficient and less psychologically taxing for the perpetrators. ${ }^{40}$ Goldhagen notes this latter point but does not seem to see how it contradicts his belief that Germans killed willingly, eagerly, and viciously. For developing the gas chambers - a means of killing that minimised contact between victim and perpetrator - should not have been necessary for a people thirsting to kill Jews en masse. The unrestrained, often sadistic violence that characterised mass shootings or death marches was not evident at gassings, which was a comparatively controlled process that distanced the killers from the victims. Rooted in the subterfuges of deception rather than the outright brutalities of sadism (most victims, told they were entering showers, did not know what fate awaited them) the gas chambers were part of a mechanised, industrialised, bureaucratically

37 James, 'Blaming the Germans', 50; Wehler, 'Wie ein Stachel', 40; Browning, 'Goldhagen's Willing Executioners', IоI-2; Peter Glotz, 'Nation der Killer', in Schoeps, Ein Volk von Mödern? I 28-9; R. C. Longworth, 'Germans' Role in Holocaust Unique? History Says Not', Chicago Tribune, 2 I Apr. I996.

38 Although not mentioning the gas chambers as such, Robert Wistrich is one of the very few critics who has pointed out how Goldhagen's analysis detracts from the unique features of the Holocaust. Wistrich, 'Helping Hitler', 3 $\mathrm{I}$. See also Hans Mommsen's similar remarks in: 'Im Räderwerk', $F A Z$, 7 Sep. I996, 37.

39 Goldhagen, Hitler's Willing Executioners, I0, I57, I65, 523 n4, 52 I n81. Goldhagen emphasises the quantitative rather than than the qualitative dimensions of the gas chambers. For example, he compares the numbers of Jews killed in shootings with those gassed ( $40 \%$ of the total) as if quantitative similarity is the same as qualitative. Similarly, he contests the 'efficiency' of the gas chambers, as if their quantitative results were as qualitatively notable as their very employment. Moreover, he attempts to elide the difference between extermination camps and 'work' camps by citing the horrifically high death rates in the latter (Goldhagen, I73). While an important observation, it reduces the uniqueness of the extermination camps. After all, in the Soviet Union under Stalin, work camps with very high mortality rates also existed.

40 See Uwe Dietrich Adam, 'The Gas Chambers', in Francois Furet, Unanswered Questions: Nazi Germany and the Genocide of the Jews (New York: Schocken Books, I989), 84-96. 
organised process of killing that was implemented by individuals (whether government bureaucrats who tallied deportation statistics, railroad officials who operated the trains, industrialists who shipped the materials for the gas chambers and ovens, or architects who designed them) who embodied the banality of evil far more deeply than, say, the members of Police Battalion Ior. That Goldhagen has shifted the focus away from such individuals to other perpetrators is to be welcomed as a means of broadening our understanding of those who were the agents of the Holocaust. But he cannot separate out the gas chambers and, at the same time, claim to have uncovered the missing piece to the larger puzzle of the Holocaust. The shootings that he so harrowingly recounts do not by themselves represent the historical caesura that the gas chambers do. As a means of mass killing, shootings were hardly unprecedented and represented merely the expansion of a proven method of murder. Any explanation of the shootings, no matter how convincing, cannot explain the Holocaust in toto, for such horrific actions did not constitute its new or unique feature. The uniqueness of the Holocaust - namely, the centralised, rationalised, and bureaucratically organised state decision to kill the Jewish people in its entirety - found its clearest and most efficient expression in the gas chambers. It is no wonder then that a much denser (if not fully opaque) veil of secrecy surrounded them than the far more public mass shootings outside eastern European towns and villages. ${ }^{41}$ As the unprecedented means of murder embodying the uniquely criminal ends of the Nazis, the gas chambers remain the singular feature of the Holocaust. Their thoroughly marginalised place in Hitler's Willing Executioners necessarily prevents Goldhagen's book from realising its most ambitious aims.

The many substantive attacks directed against Hitler's Willing Executioners, in turn, raise questions about its commercial success. How has a book that has attracted so much substantial criticism become a bestseller? It would not seem to be on the basis of pathbreaking scholarship. Although Goldhagen has a positive contribution to the larger field of Holocaust studies through his empirical case studies of Order Police killings, 'work' camps, and death marches, his book falls short of its eyecatching claim to overturn all that has preceded it. It is therefore reasonable to conclude that factors other than those usually associated with historiographical controversy, such as truly innovative scholarship, are at work. One likely reason for the commercial success of Hitler's Willing Executioners (especially in the United States) was the immediate hostile reaction to it in Germany. While advancing many of the same criticisms of Hitler's Willing Executioners as American reviewers, many German reviewers adopted a harsher tone, which revealed particular German problems with the book. The levelling of unsavoury ad hominem attacks against Goldhagen, some of which gratuitously raised the issue of the author's Jewish identity, for example, have justifiably been seen as reflecting lingering anti-Jewish attitudes in Germany. ${ }^{42}$ Such attacks, which generally questioned Goldhagen's 
personal motives and scholarly credentials for writing the book, seemed to be triggered by feelings of defensiveness and resentment and reflected deep-seated German anxieties about their nation's international image. These factors help to explain why Hitler's Willing Executioners was attacked as 'racist' and also why Goldhagen was condemned for allegedly reviving the concept of 'collective guilt' and acting like a Nuremberg prosecutor who was 'placing the whole [German] people on trial'. ${ }^{43}$ To a notable degree, such prickly retorts were rooted in political fears, especially the concern that the book's commercial success in the United States reflected American unease over German reunification. As one critic concluded, 'whoever believes the . . book can only view the Germans' path into the twenty-first century with scepticism and fear'. ${ }^{44}$ Such anxious German reactions to the book, in turn, drew still further attention to it in the United States. The mounting German criticism of Goldhagen, indeed, quickly generated an aura of international controversy and created a sensational buzz that no doubt helped to boost the American sales of the book. Paradoxically, therefore, the hostile reaction of certain German critics to Hitler's Willing Executioners undermined their very goal of downplaying its importance.

German fears notwithstanding, however, it does not appear that larger political factors have been very important in shaping the reception of Hitler's Willing Executioners. To be sure, ever since the early postwar period when Konrad Adenauer led a determined campaign to secure Germany's readmission to the community of 'civilised' nations, sensitivity to the German image abroad has been a constituent feature of German national identity. Such sensitivity has not been baseless, moreover, for at various times in the history of the Federal Republic, certain nations have, in fact, expressed deep misgivings about developments in Germany. And yet, German apprehension that similar misgivings - in this case, over reunification were behind the success of Goldhagen's book seem misplaced. Whatever fears were initially voiced in 1989-90 about reunification have proven to be unfounded today. Right-wing and neo-Nazi violence directed against foreigners has been a matter of grave concern, yet Germany has shown no signs of evolving into the aggressive, expansionist power anticipated by some. Instead, it has remained a stable and prosperous democracy, even while pursuing the difficult task of integrating the former communist East Germany. Especially compared with the far more highly charged political context of 1960-6I that helped make The Rise and Fall of the Third Reich so controversial (the neo-Nazi vandalism of $1959-60$, the Eichmann trial, the

der Geschichte', in Ein Volk von Mördern? Schoeps, 228-40. Such ill-considered attacks seems to have led certain observers such as Markovits and Josef Joffe to defend Goldhagen not so much for scholarly as for moral and political reasons. Yet, while such attacks deserved to be criticised, their significance should not be overestimated. Goldhagen's attempt to exploit the ad hominem attacks against him as evidence of his position's correctness should not distract from the fact that most of his critics have been fair and have largely focused on the shortcomings of his analysis.

43 Wehler, 'Wie ein Stachel', I4; Schirrmacher, 'Hitlers Code', 3 I; 'Ein Volk von Dämonen?' 58, 72. Jost Nolte referred to the book as 'racist' in: 'Sisyphus ist Deutscher'. Marion Gräfin Dönhoff also played the race card in 'Warum D. J. Goldhagens Buch in die Irre führt', Die Zeit, 6 Sep. 1996.

44 Schirrmacher, 'Hitlers Code', 3 I. 
Berlin crisis), there seem to be fewer larger political reasons today to explain why Goldhagen's book has caused such a stir. Indeed, while Adenauer took action to limit the influence of The Rise and Fall of the Third Reich, the closest Hitler's Willing Executioners came to producing such an effect was the then German Foreign Minister Klaus Kinkel's briefly stated objection to the concept of collective guilt in a Washington DC speech to a Jewish group - a remark made without mentioning Goldhagen's book by name. ${ }^{45}$ Since it is apparent that Hitler's Willing Executioners has not become controversial for larger political reasons, the sources of its sudden fame must lie elsewhere.

To an important degree, Hitler's Willing Executioners has gained its stature through a mixture of promotion, sensationalism, and media hype. Indeed, both German and American critics have noted such factors in analysing the reasons for the book's success. Echoing the views of many, the historian Norbert Frei noted that to obtain commercial success in the 'competitive media market', books need 'explosive theses' and the sort of provocative stance that Hitler's Willing Executioners seems to have. ${ }^{46}$ The monocausality, drastic simplification, and moralising tone of his analysis, others have argued, not only allowed Goldhagen to challenge more nuanced scholarship, but have ensured him a wide popular audience. ${ }^{47}$ Most lay readers, unfamiliar with the complexity of the subject, find such simple explanations appealing. In presenting such simple arguments, moreover, Goldhagen has been seen by German critics as having shrewdly exploited 'deep-rooted resentments and prejudices' of 'sections of the American public'. ${ }^{48}$ Similar arguments were made, it should be noted, about The Rise and Fall of the Third Reich, which was also seen at the time of its publication as having exploited American fascination with the Nazi era and prejudices against the Germans. ${ }^{49}$ Beyond its appeal to a lingering fascination with the Nazi era, Hitler's Willing Executioners has tapped into a current obsession with killers, whether serial, celebrity, or cinematic. Although its narrative is rooted in a clear moral framework, a book that focuses upon the perpetrators and includes extended graphic depictions of mass murder will inevitably attract voyeurs of the lurid in addition to other readers. ${ }^{50}$ Given the continuing commercial appeal both of the Third Reich and of murder plain and simple, it is no wonder that Hitler's Willing Executioners has garnered the attention of the mass media which, famous for

45 'Kinkel weist These von Kollektivschuld zurück', SZ, 9 May I996, I 3.

46 Frei, 'Ein Volk von Endlösern?' I 3; Konrad Kwiet, of the United States Holocaust Memorial Museum, noted the same thing at the symposium held on Goldhagen's book. See Marc Fisher, 'The German Question: Is This Holocaust an Ugly Truth - Or a Blood Libel?' Washington Post, 25 Apr. 1996. See also Johannes Heil's observation that the book is an 'example of public-oriented historiography in the media-era - concrete, firm, and shrill', in 'Stirnrunzeln erlaubt: Aus Harvard nichts Neues', Berliner Zeitung, I7 Apr. 1996. See also Hans Mommsen's comments in Jochen Arntz, 'Wenn die Dinge so einfach lägen', Berliner Zeitung, 24 Jul. 1996.

47 Nolte, 'Sisyphos ist Deutscher'; Joffe, 'Goldhagen in Germany'.

48 Wehler, 'Wie ein Stachel', 40; Birgit Weidinger, 'Vieles versäumt', SZ, 22 Jul. I996, 27.

49 Rosenfeld, 'Reception', I19-20.

50 Hans Mommsen discusses Goldhagen's depiction of violence in 'Die dünne Patina der Zivilisation' and in 'Wenn die Dinge so einfach lägen', Berliner Zeitung, 24 Jul. I996; Joffe, 'Goldhagen in Germany'. 
inflating the most mundane stories into 'newsworthy' events, predictably had a field day with such an arresting thesis as Goldhagen presents. Both in the United States and Germany, the print and visual media elevated Hitler's Willing Executioners far beyond the point it would have attained on its own scholarly merits. ${ }^{51}$ Especially in Germany, a kind of media midwifery, rooted in the desire to propel the book into the centre of a larger controversy, created an 'event' worthy of widespread media coverage. Having become a sensation partially as a result of such factors, the Goldhagen controversy appears somewhat hollow in character.

This hollowness is further demonstrated by the lack of substantive debate about the book. The first indication that a productive scholarly exchange was not in the offing appeared with Goldhagen's extended reply to his critics in Die Zeit in early August 1996. Eager to reproduce its prominent role of the I980s as a forum for the Historikerstreit, the newspaper granted Goldhagen a remarkable six pages in its weekly 'Dossier' section for him to expound on the reasons for 'The Failure of the Critics' ${ }^{52}$ In it, however, Goldhagen did not so much refute his critics as chastise them for having misread and misrepresented his book. For Goldhagen, none of the objections raised about his book were valid. The critics who aimed to 'demean' it had 'failed fundamentally', their accusations were 'hollow', 'indefensible', and 'implausible'. ${ }^{53}$ Claiming that his critics have focused mostly on his discussion of anti-Semitism (which he 'defends emphatically') Goldhagen dismissed criticism of his work by saying that his critics have themselves failed to deliver a more convincing explanation for the behaviour of the perpetrators. ${ }^{54}$ This is rather like denying one has cheated in an exam by claiming that one's accusers failed to get a better grade. To be sure, in certain instances - notably, those involving ad hominem attacks accusing him of anti-German prejudices - Goldhagen's points of rebuttal are well taken. ${ }^{55}$ But on substantive issues he has not convincingly refuted his many critics.

Most damaging is Goldhagen's dismissal of his critics' concerns regarding his failure to adopt a comparative perspective for explaining the Holocaust. He argues mistakenly that such critics intend to obscure altogether the role of anti-Semitism in the Germans' killings where, in fact, they merely object to Goldhagen's assertions of its singular German quality. ${ }^{56}$ It is incontestable, to be sure, that German killers were motivated, in large part, by anti-Semitism; yet it is only through comparison that Goldhagen's thesis for the uniquely savage, German character of the mass murders can be verified. Goldhagen evades the issue of comparison altogether,

51 That the New York Times, for example, devoted four articles to the book and its author before its publication attests to the level of media promotion. See Gulie Ne'eman Arad, 'Ein amerikanischer Alptraum', in Schoeps, Ein Volk von Mördern? 176.

52 Daniel J. Goldhagen, 'Das Versagen der Kritiker', Die Zeit, 2 Aug. I996, 9-I4. Goldhagen repeats many of the same points (now, however, with specific reference to his American critics) in his 'Motives, Causes, and Alibis: A Reply to My Critics', in The New Republic, 23 Dec. 1996, 37-45.

53 Ibid., 9.

54 Ibid., Io.

55 Ibid., I3-I4.

56 Ibid., I3. 
however, by arguing that anti-Semitism was by itself insufficient to cause the Holocaust. Clearly responding to his critics' charges of monocausality, he asserts that, in addition to widespread anti-Semitism, other factors were needed, and these were found only in Germany: the presence of a regime advocating such an ideology as state policy and the geopolitical feasibility to carry it out. ${ }^{57} \mathrm{He}$ concludes, therefore, that while other countries were antisemitic, the absence of like-minded governments advocating genocide as a policy makes them 'irrelevant' for explaining why the Holocaust happened in Germany. This claim, however, shifts the terms of the debate beyond the point that Goldhagen's book reaches. Hitler's Willing Executioners, after all, aims primarily to explain why ordinary Germans willingly killed Jews after the Nazi leadership had made such a programme into state policy. Goldhagen does not address whether other antisemitic peoples would have also killed Jews just as readily if their governments had decreed it as a primary state goal. ${ }^{58}$ Goldhagen's inability to accept criticism on this important point is indicative of the single-mindedness with which he defends his theses. Instead of engaging his critics (who, after all, include many eminent scholars in addition to less notable figures), he evasively asks, 'if my book is really as wrong as my critics claim, why have they failed to refute its most important conclusions with overwhelming proof?' Goldhagen's resistance to criticism is further indicated by his frustrated lament: 'Is it possible that so many reviewers have misrepresented my book?'59 While such comments may have been partly intended to persuade German readers to decide about the book's merits for themselves, they indicate a general failure on his part to confront his critics.

Goldhagen's apparent failure directly to address the criticisms of his book persisted, moreover, during his whirlwind speaking tour of Germany in autumn 1996. Here again a comparison with The Rise and Fall of the Third Reich is appropriate. Discouraged from speaking about his book in Germany because of possible lawsuits, Shirer ultimately concluded that it was best to 'avoid becoming embroiled in futile public debate' and to let 'the book . . speak for itself' ${ }^{60}$ Precisely at a time when public debate on the Third Reich was rare and sorely needed, Shirer's absence from Germany prevented such a discussion from materi-

57 Ibid., I2-I3. It should be emphasised that Goldhagen explicitly accepts a monocausal explanation for why ordinary Germans carried out the (already made) decision to kill the Jews. 'With regard to the motivational cause of the Holocaust . . . a monocausal explanation does suffice'. Goldhagen, Hitler's Willing Executioners, 416.

58 As Goldhagen himself says, it is not the genesis of the decision to kill the Jews but the willingness of Germans to take part in it that is his primary objective. Goldhagen, Hitler's Willing Executioners, 9, 4I6. Given this objective, he should not be concerned with establishing why the Nazis rose to power as an explanation for the Holocaust. This issue, of course, has less to do with a German tradition of anti-Semitism than with contingent factors related to the crisis of liberalism in Weimar.

59 Goldhagen, 'Das Versagen der Kritiker', I4; the large number of people who have 'misread' Goldhagen's book have led him to the rather understated conclusion that there may be a 'presentational problem' in his book; Fisher, 'The German Question'. Further evidence of Goldhagen's inability to concede any points to his critics appears in his response to Omer Bartov and Christopher Browning in New Republic, Io Feb. 1997, 4-5.

60 MDLLIU/Em, Letter from William Shirer to Fritz Epstein, 21 Sep. I96I. 
alising. In contrast, Goldhagen engaged in an outright media blitz of the Federal Republic, appearing on panel discussions of his book on German television and at several highly publicised debates in Hamburg, Berlin, Frankfurt, and Munich (in front of crowds ranging from 600 to 2,000 persons). Nowhere in Germany, however, did the much-expected fireworks erupt. Instead, Goldhagen and his 'critics' engaged in a rather civil exchange in which Goldhagen notably won considerable popular sympathy. The reasons for this extremely surprising response were several. For one, Goldhagen evidently moderated his strident views while in Germany. Rather than acting as the firebrand author one would expect from reading his book, he disarmed his critics by exhibiting what various observers have described as 'charisma' and 'charm' and pre-empted their objections to his theses by backtracking from his prior stridency. Goldhagen's moderation, which was echoed in the softened German translation of Hitler's Willing Executioners, helped him win over his audiences by making him appear gracious, while his critics, Hans Mommsen in particular, came across as overly critical, scholastic, and petty. ${ }^{61}$ Goldhagen's German critics acquired a negative image, moreover, despite having moderated their own objections to his position. Perhaps fearing for their own reputations in the light of Goldhagen's burgeoning popularity, critics who were quite harsh towards Goldhagen in April 1996, such as Norbert Frei and Rudolf Augstein, appeared more collegial during his recent tour of Germany. Some, such as Jan Phillip Reemtsma, even defended some of his assertions. ${ }^{62}$

Given the fact that Goldhagen and his critics generally talked past one another in Germany, the doubts, expressed early on by various observers, that Hitler's Willing Executioners would provoke a new Historikerstreit seem to be confirmed. ${ }^{63}$ Compared with previous historiographical debates, there does not appear to be much that is substantive behind the controversy surrounding Goldhagen's book. Thus, while the Historikerstreit was a genuine barometer of political infighting over the future course of Germany's national identity, and while the controversy over The Rise and Fall of the Third Reich reflected real concerns in the early I960s over the implications of the nation's Nazi past on its future development, the controversy over Goldhagen's book

61 In the German translation, Goldhagen no longer claims to have written a 'radical revision' of all prior scholarship and generally softens his prior indictment of the German people. Jost Nolte, 'Die Kunst es nicht gesagt zu haben', Die Welt, 2 Sep. I996; “"Riesige Mehrheit”,, Der Spiegel, 33 (I996), 42. Whether or not this was Goldhagen's decision or his German publisher's, it is worth noting the contrast, yet again, with Shirer's The Rise and Fall of the Third Reich, whose German publisher, Kiepenheuer \& Witsch, ultimately abandoned initial plans to purge the book's 'anti-German' sections and let it stand on its own merits. MDLLIU/Em, Letter from Carola Stern of Kiepenheuer \& Witsch to Fritz Epstein, 8 Mar. I96I; letter from J. C. Witsch to Fritz Epstein, I7 Apr. I96I.

62 Evelyn Roll, 'Eine These und drei gebrochene Tabus', SZ, 9 Sep. 1996; Cornelia Bolesch, 'Historie oder Hysteria', SZ, 6 Sep. 1996. Jost Nolte, 'Die Kunst es nicht gesagt zu haben', Die Welt, 2 Sep. 1996; Katja Ridderbusch, "'Mit dieser Reaktion habe ich nicht gerechnet", Die Welt, 7 Sep. 1996. 'Holocaust Writer Debates Irate Historians in Berlin', New York Times, 8 Sep. I996; Volker Ullich, 'Die Buchtournee wurde zum triumphzug', Die Zeit, I3 Sep. I996; Jan Phillip Reemtsma, 'Die Mörder waren unter uns', $S Z, 24$ Aug. 1996.

63 Heil, 'Stirnrunzeln erlaubt'; Frei, 'Ein Volk von Endlösern?' I3; 'Willige Vollstrecker', SZ, 2 Aug. I996, 29; Jost Dülffer, 'Eine Zauberlehrling und seine Widersprüche', Berliner Zeitung, 6 Aug. I996. 
does not seem to reflect the presence of larger political factors. One could not be blamed, therefore, for coming to the simple conclusion that the controversy over Hitler's Willing Executioners has, to a large extent, been produced by a combination of its own internal weaknesses and the immense publicity given to it by the mass media.

Still, the controversy over Hitler's Willing Executioners provides certain lessons about current perceptions about the Holocaust. For one, it supplies further proof of the continuing gap between popular and scholarly views of the Holocaust. Scholars, it is clear, have rejected the book's central assertions nearly unanimously; many, indeed, want to hear no more about it, as was demonstrated by the refusal of German historians to debate the book anew at the German Historikertag in Munich in September $1996 .{ }^{64}$ Yet, as discussions of the book in the United States and Germany have shown, the generally laudatory reaction of the public to Goldhagen's arguments and the critical response to those of his opponents seem to indicate widespread sympathy for Goldhagen's simple explanation of the Holocaust. Among Jews, both in the United States and Germany, this reaction is predictable - especially among Holocaust survivors who, Goldhagen says, have approved of his conclusions wholeheartedly. ${ }^{65}$ Not all Jews, of course, share Goldhagen's sweeping views; important European Jewish leaders such as Ignaz Bubis and Simon Wiesenthal have criticised Goldhagen's thesis publicly. ${ }^{66}$ Many, however, have long shared Goldhagen's radically intentionalist position and have supported his emphatic confirmation of it.

What is more surprising is Goldhagen's popularity in Germany. Especially in the light of the hostile press response to Hitler's Willing Executioners in April 1996, the more recent support displayed for Goldhagen in Germany demands explanation. Although some degree of this popularity can be attributed to Goldhagen's prominent media exposure, much more of it may reflect new trends in the Germans' process of 'coming to terms' with the Nazi past. The willingness of a young generation of postwar Germans finally to 'unearth the repressed knowledge' of their elders' wartime crimes has been noted by many observers. ${ }^{67}$ The embrace of Goldhagen's book, according to this view, reflects a new desire of Germans to accept the full moral responsibility for the historical evil committed by their compatriots. One must be careful, of course, not to overestimate the current level of German support for Goldhagen. After all, what has been described as his 'triumphal parade' through Germany has been based largely on book sales and, perhaps more importantly, audience response at his public speaking engagements. ${ }^{68}$ While these

64 'Schreckbild oder Vorbild?' Berliner Zeitung, 21 Sep. I996.

65 Indicative of this feeling was a letter to the editor sent to the Jewish Journal of Los Angeles, entitled 'Goldhagen is right', by David Brook, I9-25 Jul. I996, 4.

66 Wiesenthal kritisiert Goldhagen', Berliner Zeitung, 23 Aug. 1996; Jochen Arntz, 'Der Freund der Deutschen', Berliner Zeitung, 7 Sep. 1996. See also 'Enough Goldhagen', Jewish Journal, I I-I7 Oct. I996, 3 .

67 Josef Joffe, 'Goldhagen in Germany', Volker Ullrich, 'Die Buchtournee wurde zum Triumphzug', Die Zeit, I 3 Sep. I996; Jochen Arntz, 'Der Freund der Deutschen', 'Im Räderwerk', FAZ, 7 Sep. I996, 37 .

68 Ullrich, 'Die Buchtournee wurde zum Triumphzug'. 
audiences were no doubt mixed, their representativeness of the nation at large is uncertain; they were not only relatively small but may have been constituted, to a significant degree, by the converted who came to hear the words of their favourite preacher. Moreover, the appearance of ad hominem attacks against Goldhagen in Germany - claiming, among other things, that he may be responsible for stirring up anti-Semitism - also shows that German support for his work is hardly unanimous. ${ }^{69}$ Nevertheless, the considerable German attention to Hitler's Willing Executioners confirms the commonly made assertion that, despite the recent fiftieth anniversary commemorations of the end of the Third Reich and the Second World War, no final line (Schlußstrich) can, as yet, be drawn under the Nazi past. ${ }^{70}$

This conclusion, however, is far less interesting than the surfacing of actual support for Goldhagen's thesis. It is noteworthy that at least a minority of Germans have accepted the most scathing of verdicts upon the most shameful aspect of their nation's past. Various German critics have noted the significance of this trend and have welcomed it. Writing that 'one can be a bit proud of this reaction', Josef Joffe has described the support of 'ordinary Germans' for Goldhagen's head-on confrontation with the horror of the Holocaust as a deed that 'honours them'. ${ }^{71}$ NonGerman critics also have voiced similar feelings, such as the Israeli journalist, Amos Elon, who praised the Germans' openness to Goldhagen's message and commended the decision of the Bonn-based Journal for German and International Politics to award Goldhagen its Democracy Prize. ${ }^{72}$ To be sure, it is both worthy and necessary for Germans to confront the crimes committed against the Jews under the Nazi regime. And yet, the acceptance of Goldhagen's simple explanation of the Holocaust gives cause for concern. For in accepting Goldhagen's thesis, a significant number of Germans have ignored some serious flaws in his book. This apparent lapse in critical judgement may have several explanations. In part, it may be due to a lack of selfconfidence among Germans to evaluate a work of scholarship delivered by a 'representative' of the victims (Goldhagen, it is well known, is not only Jewish but also the son of a Holocaust survivor). The uncritical embrace of Goldhagen's problematic study further testifies to a general yielding to emotion among his German supporters. This is the conclusion of certain German critics, such as Hans Mommsen, who have spoken of 'the German public's flight into irrationality'. ${ }^{73}$

69 This belief was expressed in Marion Gräfin Dönhoff's article, 'Warum D. J. Goldhagens Buch in die Irre führt'. For a comment on this position see Josef Joffe, 'Die Hunde schlafen schlecht', SZ, 24 Sep. 1996. For other hostile reactions see letters to the editor in Der Spiegel, I 8 (I996).

70 As Jost Nolte wrote in Die Welt, although it finally appeared that the Germans had been redeemed from the fate of sisyphus, Goldhagen . . . showed them back to damnation'. Nolte, 'Sisyphos ist Deutscher'; Wehler, 'Wie ein Stachel', 40; Frei, 'Ein Volk von Endlösern?' I3; Joffe, 'Hitlers willfährige Henker', I3.

71 Josef Joffe, 'Das Goldhagen-Phänomen', SZ I I Sep. 1996, 4. Stephan Speicher also sees an emotional response as better than a rational one, noting that 'differentiation seems inappropriate in view of the reality of the murder of the Jews'. 'Wortstark', FAZ, 7 Sep. 1996, 35.

72 Amos Elon, 'The Antagonist as Liberator', New York Times Magazine, 26 Jan. 1997, 40-4.

73 Elisabeth Bauschmid, 'Ein Erfolg mit Konsequenzen', SZ, 2 I Sep. I996. The leading CDU politician Wolfgang Schäuble likewise speaks of the 'irrationality of our era's debates' in 'Zeitgespräch 
More moderate critics, such as Jürgen Kocka, have described the embrace of Goldhagen's work as the result of the preference for an emotional catharsis rather than for more differentiated and 'scientific' historical explanations - the very same needs that elevated the television docudrama, Holocaust, in 1979, and the film Schindler's List in 1994 to such heights of popularity. ${ }^{74}$ The graphic narrative of Hitler's Willing Executioners and its straightforward analytical explanation may well provide some readers with a ready cathartic release. But, like the two films before it, one wonders about its long-term contribution to deeper historical understanding. To be sure, historical understanding is not the sole means of coming to terms with the past. Many critics in 1979, for example, tolerated Holocaust's historical and aesthetic flaws in the light of its pedagogical and political virtues - in particular, its prompting of an emotional confrontation with the Holocaust at a time when the moral lessons of the Nazi past seemed to be fading. ${ }^{75}$ Nearly twenty years later, however - especially after the commemorative wave of the I980s and early I990s public awareness of the Holocaust has moved well beyond the point where simply any degree of attention to it, regardless of scholarly merit, is salutary.

Indeed, it can be argued that an emotionally driven confrontation with the Holocaust may have the effect of discouraging a thorough reckoning with it. One senses that the popular embrace of Goldhagen's view of the Holocaust is partially rooted in impatience, in the desire finally to attain an easily comprehensible, emotionally satisfying explanation for an event that scholars have either described in complex, distanced terms or regarded as ultimately inexplicable. ${ }^{76}$ Such impatience may be rooted, moreover, in the wish of some Germans finally to escape the burden of guilt for the Holocaust altogether. By accepting the simplest of all imaginable explanations of the Holocaust, after all, one no longer needs to grapple further with its most unfathomable dimensions. The embrace of a book which claims finally to have resolved the fundamental problem of the Holocaust, therefore, may well reflect the desire to forget rather than to remember the Nazi crimes. For after accepting Goldhagen's uncompromising explanation of the Holocaust and the historical legacy of guilt which it entails, what further measures can Germans

mit Wolfgang Schäuble: "Wir brauchen mehr Streit", Die Zeit, 20 Sep. 1996. Peter Schneider likewise finds German support for Goldhagen 'disturbing'. 'For Germans, Guilt Isn't Enough', New York Times, 5 Dec. 1996.

74 'Holocaust Writer Debates Irate Historians in Berlin', New York Times, 8 Sep. 1996; Frank Schirrmacher, 'Wunderheiler Goldhagen', I 3 Sep. I996, FAZ, I. Joffe, 'Goldhagen in Germany'.

75 During the late I970s, the nostalgic 'Hitler Wave', the Filbinger Affair, and the Bundestag Verjährungsdebatte (over waiving the statute of limitations for Nazi war crimes), raised concerns among certain observers that the Nazi past had ceased to be a moral touchstone for many Germans. See the various articles on the reception of the film Holocaust in West Germany in Anson Rabinbach and Jack Zipes (eds.), Germans and Jews Since the Holocaust (New York: Holmes and Meier, 1986), 185-283.

76 This explanation is supported by the apparent lack of trust of young Germans in their own nation's historians, who have been criticised for avoiding the horrific dimensions of the Holocaust in their writings in favour of a more detached, analytical focus on its origins. While this generational tension is not wholly surprising, the fact that it seems to entail the elevation of foreign historians of the Holocaust (such as Goldhagen), no matter what the merit of their positions, is clearly problematic. See 'Im Räderwerk', FAZ, 7 Sep. 1996, 37. 
possibly take to come to terms with the Nazi past? Accepting Goldhagen's conclusions seems tailor-made, therefore, to draw the proverbial Schlußstrich under the Nazi past. And yet, one wonders whether most Germans have truly recognised the severity of Goldhagen's verdict. Ironically enough, Goldhagen's tough medicine may in fact be quite easy to swallow. His claim (contained in a much-celebrated footnote and frequently voiced in public) that, after 1945, the re-education of the Germans banished the antisemitic curse for good, actually may serve to free contemporary Germans from the fear - commonly held by scholars who see modern forces at work in genocide - that their nation might once again repeat the crimes of its antisemitic past. ${ }^{77}$ While it is difficult to know how widespread such feelings may be, the rupture that Goldhagen identifies between the Third Reich and the Federal Republic makes it easier for younger Germans to confront the crimes of the Nazis. After all, how painful can it be for this generation, more than fifty years since the Holocaust, to hear their grandparents' generation indicted? It is this historical distance that no doubt helps explain the readiness of some Germans to accept Goldhagen's message. As noted above, however, this readiness should not be praised too quickly. For by accepting the conclusions of Hitler's Willing Executioners, Germans may not so much be helping to preserve the past in memory as obviating the further need to wrestle with its profoundly disturbing implications.

It is too early to predict whether or not the controversy surrounding Hitler's Willing Executioners will constitute a final expression, or merely a new phase, in the German struggle with the Nazi past. The task of Vergangenheitsbewältigung, after all, is one of uncertain duration, seemingly finished at one moment only to resurface at the next. Assertions, for example, that the cathartic German reaction to the docudrama Holocaust in 1979 represented the long-awaited overcoming of the inability to mourn and an open encounter with the full nature of the Nazi past were confounded by the eruption of the Bitburg Affair in 1985 and the Historikerstreit the year after. ${ }^{78}$ There is much to suggest that the legacy of the Third Reich and the Holocaust will never be fully mastered, if by 'mastered' a point of completion or finitude is thereby implied; rather, it is more likely that these traumatic episodes in Germany's national past will be continually worked through in a dialectical manner over time. Indeed, in the same way that the docudrama Holocaust (and the film, Shoah, by Claude Lanzmann) helped spawn Edgar Reitz's normalised depiction of everyday life under the Nazis in his film, Heimat, several years later, Hitler's Willing Executioners will probably spark some type of backlash and help usher in new works of history contesting those dimensions of the Holocaust that Goldhagen identifies as

77 Goldhagen, Hitler's Willing Executioners, 593 n53. Goldhagen, however, seems to ignore the observations of historians who have discussed the numerous problems and limited success of reeducation after I945. Today, Goldhagen openly notes, the Germans are 'like us'. Dinitia Smith, 'Challenging a View of the Holocaust', New York Times, I Apr. I996, BI.

78 Jeffry Herf, 'The Holocaust Reception in West Germany', in Rabinbach and Zipes (eds.), Germans and Jews Since the Holocaust, 2 I 7. 
quintessentially German. ${ }^{79}$ Regardless of what it may evoke from others in the future, however, Goldhagen's book has already assumed a place in the long ongoing German struggle with its past.

And yet, whatever its ultimate historic importance, the controversy surrounding Hitler's Willing Executioners will probably do little to bolster its scholarly reputation. It seems likely that the book will be remembered more for the reaction it caused than for the value of the argument it presented. Although considerable attention has recently been placed on the book's salutary function as a means to a desired end that of leading today's 'ordinary Germans' to confront the horrors of the Holocaust - such standards should not, in the long run, be used to judge the book's ultimate value. Should they be, then any author could gain recognition by advancing a radical (and not so easily defensible) thesis, so long as it sparks controversy. And while the generation of a public response is certainly one of the achievements of Goldhagen's book, such an accomplishment should not be allowed to define the standards for distinguished scholarship now or in the future. Most probably, once the furor dies down, the book will be judged on its intrinsic merits and seen as wanting. It is unlikely that, over time, Hitler's Willing Executioners will attain a reputation comparable with that of, say, The Rise and Fall of the Third Reich. This will probably be the case for several reasons. Goldhagen's book, for one, is simply less readable than Shirer's, the latter being a gripping tale written by an experienced journalist, whereas the former, while harrowing in its details, is much too repetitive, cluttered with cumbersome social scientific formulations, and too academic in style to retain a large popular audience. Neither will the already unfavourable reputation of Hitler's Willing Executioners among scholars improve in the long run. Compared with Shirer's study which, as a largely descriptive narrative of the Third Reich's origins, did not harbour lofty scholarly pretensions, Goldhagen's more analytically ambitious work has fallen quite short of its intended goal. The controversy over Hitler's Willing Executioners may well reflect new trends in the memory of the Holocaust, but the absence of broader factors underlying the furor suggests that the book's reputation will diminish over time. Meanwhile, one can only hope that it does not do more harm than good.

79 The recent attacks by right-wing groups in Munich against Jan Reemtsma's travelling exhibition on Wehrmacht crimes during the Second World War has been seen as a sublimated kind of backlash against Goldhagen's book. See Michael G. Esch's contribution to the discussion of the Wehrmacht exhibition on H-Holocaust, Io Mar. 1997. Other critics, such as those associated with the journal, The Genocide Forum, have challenged Goldhagen's 'privileging [of] anti-Semitism' in explaining the Holocaust and call for 'contextualising . . . the Holocaust into Genocide Studies'. See essays by Henry Huttenbach and Jonathan Petrie in The Genocide Forum, June 1996, I-3. 